\title{
THE STUDY OF BOTANY THIRTY-SIX YEARS AGO WITH ASA GRAY.
}

\author{
By W. J. BeaL. \\ Professor of Botany, Michigan Agricultural College.
}

It is hardly fair to compare the work of botanists and zoölogists who were active thirty-six years ago with those now in their prime. Although often stated in educational journals, it is rarely comprehended by students of today that a knowledge of these subjects has advanced more within the past fifteen to twenty years than in all former years combined.

As a resident graduate, I took my degree at Harvard in $186_{5}$. At that time there were only two persons in America earning all their living by teaching and other work in botany, and they were Asa Gray, of Harvard, and D. C. Eaton, of Yale. A considerable number of other universities and colleges gave a little botany in the course, but this was taught by persons each teaching several other subjects.

How much time was required of undergraduate students in the study of botany? At Harvard and at the University of Michigan it amounted to a grand total of six weeks of daily work on one study out of three or four pursued at the same time. I know of no college in the United States which required students to devote more than six weeks to botany, save one, and that was the Michigan Agricultural College, where very nearly a year of daily work was required. No undergraduate of the institutions named could elect any more botany than above mentioned excepting at Harvard, where three or four weeks of daily work might be spent in identifying plants with help from the teacher.

Dr. Gray assigned lessons in his larger text book and students were thoroughly questioned over the ground with an abundant supply of fresh specimens to illustrate each topic. No drawings were made on the blackboard. There were four sections of the sophomore class of about twenty-five each. The time for a lesson was one hour. Much stress was placed on morphology,-in comparing corresponding parts of different plants with each other.

$\mathrm{J}$ must modify my statement of the work in botany at Harvard 
by saying that once during a period of six years, Dr. Gray gave a short course of illustrated lectures on geographical botany, a course not fully appreciated by most students for want of previous study. This course was elective. The botanical department of Harvard did not possess a single compound microscope, but had a costly one in its possession. The field of work at that time open to botany consisted chiefly in describing and naming and classifying dried specimens which were frequently incomplete. This is known as systematic botany, but at that time almost no account was made of the minute structure of the plant as seen with the aid of a compound microscope, nor was much attention paid to the various stages of development of the parts. The work was based on the gross anatomy of plants as seen by a hand lens. The modes of collecting and pressing herbarium specimens were crude when compared with that of our best collections of these times. The reader will note that the time of the botanist of 1865 was chiefly devoted to systematic botany, morphology and the geographical distribution of plants. These were three fields of work closely related.

Dr. Gray employed no clerk, but performed a great amount of "dead work" with his own hands. All letters were written by himself with pen and ink. He was often brief in his replies, but in many cases his letters were full of interesting points, anecdotes and plans of work to be done. His letters were social and confidential, as well as scientific. A girl mounted plants for the herbarium.

A very small number of resident graduates-one to three at a time-learned botany under the guidance of Dr. Gray. For plant anatomy, we read Mohl on the Vegetable Cell translated; only this and nothing more, for little else was to be had that was valuable, and this work was laid on the shelf as imperfect and out of date years and years ago.

We read Lindley's Vegetable Kingdom, identified hundreds and hundreds of dried plants, when we couldn't get them fresh from the fields, botanic gardens or the woods. We tried our hands at original descriptions and made artificial keys. We noted all the points which characterized the families. of plants. Very little time was spent on plants below the ferns and their allies. 
Let us take one long step in time from I865 to r9or, and note a few of the leading points concerning plants that are now demanding the attention of students. New worlds have been discovered and each is now well taught in many colleges. I mentioned three above. We have them still, with additions, and five at least have been added, viz.: Plant histology, plant physiology, ecology, bacteriology, parasitic fungi and saprophytic fungi. Through the rapid development of agricultural colleges and work in the United States Department of Agriculture, opportunity was offered to earn money by a knowledge of plants. The universities soon gave a greater opportunity to elect botany than ever before. Today I dare not attempt to name or enumerate the hundreds of persons in this country, all of whom get their living by work with plants. Progress in every line is most marked, as we might expect where so many well-trained enthusiasts are occupying so many different fields. Botarıy in any of its departemnts is a charming and valuable study for pleasure, information, discipline or culture.

The older botanists of today have been obliged to bestir themselves continually to keep atreast of the times. They consult each other by letter, in person, or meet in conventions. They visit a number of the best equipped laboratories of this country or of Europe and remain as students or remain long enough to secure many hints that will be of value in wcrk with their own classes. Without this, they would soon be shelved, or teach the old botany with none of the new.

\section{THE HIGH SCHOOL LIBRARY FOR CHEMISTRY.}

J. BISHOP TINGLE, PH. D.

Professor of Chemistry, Illinois College, Jacksonville, Ill.

Most teachers will probably agree that the provision of a library for the Chemical Departments of secondary schools is almost as essential to their complete efficiency as, say, an adequate supply of test tubes and flasks; yet it undoubtedly happens that, 